\title{
KAJIAN KUALITAS AIR LAUT DI PERAIRAN KOTA BONTANG PROVINSI KALIMANTAN TIMUR
}

\section{(STUDY OF THE QUALITY OF THE WATER ENVIRONMENT IN BONTANG CITY, EAST BORNEO PROVINCE)}

\author{
Noor Wahyuningsih, Suharsono, Zhikry Fitrian \\ Balitbangda Prov. Kaltim \\ Jalan MT. Haryono No. 126 Samarinda, Kaltim \\ Email: yu_ni05@yahoo.com
}

Diterima: 2 Desember 2021; Direvisi: 22 Desember 2021; Disetujui: 24 Desember 2021

\begin{abstract}
ABSTRAK
Kualitas perairan sangat dipengaruhi oleh aktivitas yang terjadi di sekitar perairan tersebut. Aktivitas perairan yang semakin tinggi lambat laun akan mengakibatkan penurunan kualitas perairan baik secara fisik, kimia maupun biologi yang pada akhirnya akan menurunkan kualitas dan kuantitas sumberdaya pesisir dan laut. Kota Bontang sebagai salah satu daerah di Kalimantan Timur terkenal dengan hasil perikanannya berupa hasil laut dan hasil olahan perikanan, selain itu juga dikenal sebagai kota industri tentunya kegiatan pemantauan lingkungan melalui pengujian kualitas air harus dilakukan. secara teratur. Penelitian ini dilakukan untuk mengetahui status kualitas air laut berdasarkan parameter fisik, kimia dan biologi di perairan Kota Bontang. Pengambilan sampel kualitas air dilakukan pada bulan November 2020 di 6 (enam) stasiun penelitian menggunakan botol niskin dan dianalisis di laboratorium Pusat Penelitian dan Standardisasi Industri Samarinda, kemudian hasilnya dibandingkan dengan baku mutu air laut untuk biota laut berdasarkan Keputusan Menteri Lingkungan Hidup. Nomor 51 Tahun 2004 Hasil penelitian menunjukkan bahwa parameter yang tidak sesuai dengan baku mutu meliputi parameter suhu, pH, Total Suspended Solid (TSS), Amonia, Nitrat, Timbal dan Total Coliform. Parameter yang melebihi baku mutu akan berdampak pada terganggunya fungsi ekologi ekosistem di perairan dan terjadinya penurunan kualitas air laut baik secara fisik, kimia maupun biologi yang berakibat pada penurunan daya guna, hasil guna, produktivitas, daya dukung dan daya tampung sumberdaya perairan sehingga pada akhirnya akan menurunkan kekayaan sumberdaya alam.
\end{abstract}

Kata Kunci: Kota Bontang, kualitas perairan, perikanan

\begin{abstract}
The quality of the waters is greatly influenced by the activities that occur in the vicinity of these waters. Increasingly high water activity will gradually result in a decrease in water quality both physically, chemically and biologically, which in turn will reduce the quality and quantity of coastal and marine resources. Bontang as one of the city in East Kalimantan is famous for its fishery products of the form of marine products and processed fishery products, but it is also known as an industrial city, of course environmental monitoring activities through water quality testing must be carried out regularly. This research was conducted to determine the status of seawater quality based on physical, chemical and biological parameters in the waters of Bontang. Water quality sampling was carried out in November 2020 at 6 (six) research stations using niskin bottles sample and analyzed at the Samarinda Industrial Research and Standardization Center laboratory, then the results were compared with seawater quality standards for marine biota based on the Minister of Environment Decree Number 51 of 2004 The results showed that the parameters that were not in accordance with the quality standard included parameters of temperature, pH, Total Suspended Solid (TSS), Ammonia, Nitrate, Lead and Total Coliform. Parameters that exceed the quality standard will have an impact on disrupting the ecological function of ecosystems in the waters and the occurrence of a decrease in the quality of sea water physically, chemically and biologically which results in a decrease in usability, usability, productivity, carrying capacity and capacity of aquatic resources so that in the end it will reduce natural resource wealth.
\end{abstract}

Keywords: Bontang city, water quality, fishery 


\section{PENDAHULUAN}

Kota Bontang secara administratif merupakan bagian dari Provinsi Kalimantan Timur yang memiliki luas 469.752,56 Ha dengan luas daratan hanya 29\% dari total luas yang ada sehingga $71 \%$ daerahnya merupakan wilayah perairan. Perairan Laut Kota Bontang sendiri merupakan bagian dari wilayah Selat Makasar, dimana lokasi umum kegiatan yang ada di perairan laut tersebut yaitu Pelabuhan Lok Tuan sebagai pelabuhan peti kemas, pelabuhan tanjung laut sebagai pelabuhan bagi barang-barang lokal terutama dari wilayah Sulawesi serta Pantai Bontang Kuala sebagai tempat pariwisata dan pemukiman. Selain itu, terdapat aktivitas industri besar yang berada di sekitar lokasi perairan yaitu PT. Pupuk Kaltim beserta kawasan industry petrokomia, Badak NGL yang bergerak dibidang gas dan Perusahaan Batubara PT. Indominco Mandiri. Aktivitas perairan dan disekitarnya yang cukup banyak tentunya akan berkontribusi terhadap perubahan kualitas lingkungan perairan yang dapat mengganggu fungsi ekologi ekosistem di perairan dan terjadinya penurunan kualitas air laut baik secara fisik, kimia maupun biologi.

Hampir di sepanjang pesisir perairan Kota Bontang merupakan wilayah yang produktif yang dimanfaatkan oleh masyarakat sekitar untuk aktivitas perekonomian. Kota Bontang pun dikenal dengan hasil perikanannya baik hasil laut maupun berupa produk olahan perikanannya. Sehingga kualitas dan pengendalian pencemaran air laut harus dilakukan untuk menjaga potensi wilayah perairan tetap terjaga dan memberikan manfaat bagi masyarakat, karena terjadinya kerusakan lingkungan akan mengakibatkan menurunya profuktifitas sehingga akan menurunkan perekonomian masyarakat terutama para nelayan (Cordova, 2011).

Salah satu usaha pengendalian pencemaran yaitu dengan pemantauan kualitas perairan karena umumnya permasalahan dominan bagi wilayah pesisir, pantai maupun laut yaitu terjadinya pencemaran yang mengakibatkan penurunan kualitas dan kuantitas sumberdaya pesisir dan laut yang akan berdampak pada penurunan daya guna, hasil guna, produktivitas, daya dukung dan daya tampung dari sumberdaya perairan sehingga pada akhirnya akan menurunkan kekayaan sumberdaya alam.

Penelitian ini dilakukan untuk mengetahui kualitas perairan Kota Bontang Provinsi Kalimantan Timur namun hanya difokuskan pada beberapa parameter fisika, kimia dan biologi perairan yang tertera dalam baku mutu air laut untuk biota laut. Harapannya, hasil dari penelitian ini dapat memberikan informasi dasar dan dapat memberikan manfaat baik bagi masyarakat maupun pemerintah daerah terutama sebagai bahan masukan dalam pengelolaan wilayah perairan di Kota Bontang.

\section{METODE}

\section{Lokasi dan Waktu Penelitian}

Penelitian ini dilakukan pada Bulan November 2020 berlokasi di perairan laut Kota Bontang yang masuk dalam wilayah Selat Makasar, Provinsi Kalimantan Timur. Titik pengukuran dan pengambilan sample air laut dilakukan sebanyak 6 (enam) stasiun dimana mewakili karakteristik berbeda pada setiap stasiunnya. (lihat tabel 1 dan gambar 1).

\section{Metode Pengumpulan Data}

Pengambilan sampel air dilakukan dengan menggunakan metode botol niskin pada kedalaman 1 meter, sampling dilakukan di 6 (enam) stasiun dengan ulangan sebanyak 2 kali perstasiun untuk pengukuran kualitas air insitu. Sedangkan untuk pengambilan sampel air laut yang memerlukan analisis laboratorium dilakukan dengan memasukkan sampel air laut ke dalam botol niskin dan disimpan dalam coolbox untuk dianalisis di Laboratorium Balai Riset dan Standarisasi Industri Samarinda (Baristan Samarinda). 
Pengambilan sample air tersebut dilakukan pada beberapa lokasi dan terbatas pada beberapa parameter kimia, fisika dan biologi dengan pertimbangan bahwa lokasi serta parameter yang diukur menggambarkan kondisi kualitas lingkungan di perairan Kota Bontang.

Tabel 1. Koordinat Lokasi Pengambilan Sampel

\begin{tabular}{llll}
\hline Stasiun & & Longitude & Latutide \\
\hline Lok Tuan & LT1 & $117^{\circ} 29^{\prime} 52^{\prime \prime} \mathrm{E}$ & $00^{\circ} 09^{\prime} 88^{\prime \prime} \mathrm{N}$ \\
(Sekitar Pelabuhan Lok Tuan) & LT2 & $117^{\circ} 29^{\prime} 55^{\prime \prime} \mathrm{E}$ & $00^{\circ} 09^{\prime} 42^{\prime \prime} \mathrm{N}$ \\
Bontang Kuala & $\mathrm{BK} 1$ & $117^{\circ} 32^{\prime} 01^{\prime \prime} \mathrm{E}$ & $00^{\circ} 09^{\prime} 22^{\prime \prime} \mathrm{N}$ \\
(Pemukiman \& Wisata) & $\mathrm{BK} 2$ & $117^{\circ} 33^{\prime} 04^{\prime \prime} \mathrm{E}$ & $00^{\circ} 08^{\prime} 45^{\prime \prime} \mathrm{N}$ \\
Tanjung Laut & $\mathrm{TL1}$ & $117^{\circ} 31^{\prime} 57^{\prime \prime} \mathrm{E}$ & $00^{\circ} 05^{\prime} 36^{\prime \prime} \mathrm{N}$ \\
(Sekitar Pelabuhan Tanjung Laut) & $\mathrm{TL2}$ & $117^{\circ} 30^{\prime} 24^{\prime \prime} \mathrm{E}$ & $00^{\circ} 06^{\prime} 20^{\prime \prime} \mathrm{N}$ \\
\hline
\end{tabular}

Sumber : Hasil Analisis (2020)

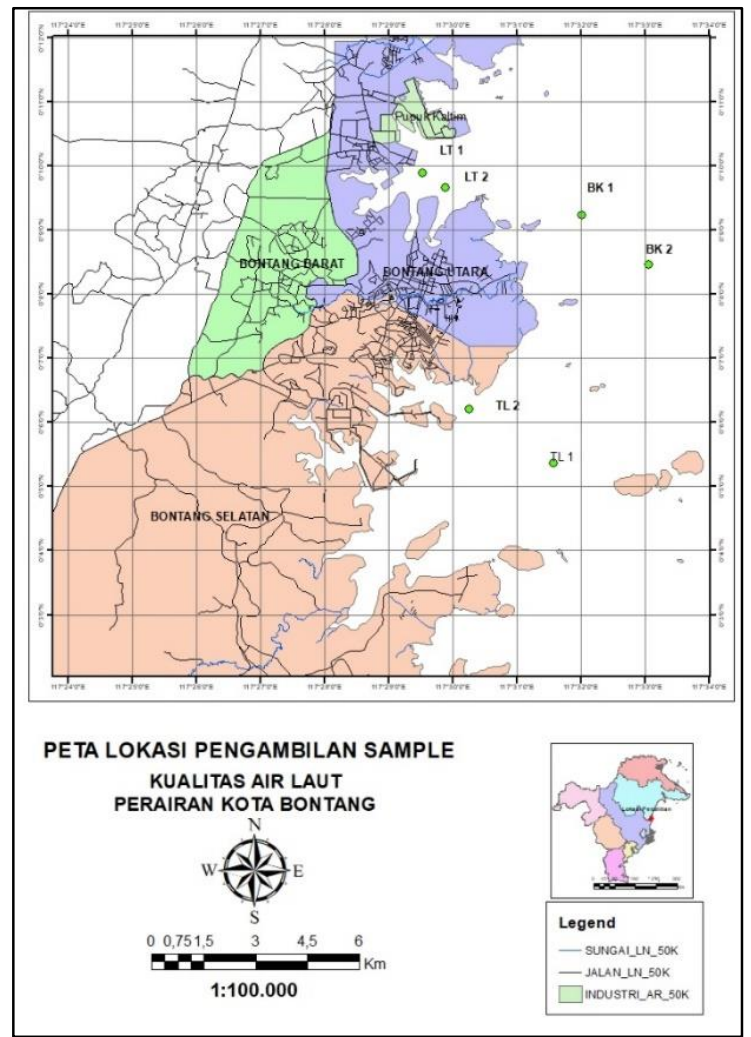

Gambar 1. Peta Lokasi Penelitian

Sumber : Hasil Analisis (2020)

\section{Metode Analisis Data}

Adapun jenis parameter fisika, kimia dan biologi air laut yang diuji dalam penelitian ini, serta metode pengukuran dan standar analisis yang digunakan disajikan pada Tabel 2. Analisis data hasil pengukuran insitu dan hasil analisis laboratorium parameter kualitas air dilakukan secara deskriptif, yaitu dengan membandingkan hasil yang diperoleh dengan baku mutu kualitas air laut berdasarkan Keputusan Menteri Negara Lingkungan Hidup No. 51 Tahun 2004 tentang Baku Mutu Air Laut. Dengan parameter fisika dan kimia untuk biota laut, sedangkan parameter biologi untuk baku mutu kualitas air laut wisata bahari.

Tabel 2 Parameter dan Metode Analisis Kualitas Air Laut 
Kajian Kualitas Air Laut di Perairan Kota Bontang Provinsi Kalimantan Timur

Noor Wahyuningsih, Suharsono, Zhikry Fitrian

\begin{tabular}{llc}
\hline \multicolumn{1}{c}{ Parameter } & \multicolumn{1}{c}{ Tipe Analisis } & Spesifikasi Alat/ Metode Analisis \\
\hline $\begin{array}{c}\text { Parameter Fisika } \\
\text { Suhu }\end{array}$ & \multicolumn{1}{c}{ Insitu } & Thermometer \\
TSS & Lab. Baristan samarinda & SNI 06-6989.3-2004 \\
Parameter Kimia & \multicolumn{1}{c}{ Insitu } & \\
pH & \multicolumn{1}{c}{ Kertas Lakmus } \\
BOD & Lab. Baristan samarinda & SNI 6989.72:2009 \\
Amonia (NH3) & Lab. Baristan samarinda & SNI 19-6964.3-2003 \\
Fosfat & Lab. Baristan samarinda & SNI 06-6989.31-2005 \\
Nitrat (NO3-N) & Lab. Baristan samarinda & SNI 06-2480-1991 \\
Raksa (Hg) & Lab. Baristan samarinda & SNI 19-6964.2-2003 \\
Arsen (As) & Lab. Baristan samarinda & IK/LAB/7.2.108 (In House Method \\
& & AAS-HVG \\
Kadmiun (Cd) & Lab. Baristan samarinda & SNI 06-6989.38:2005 \\
Tembaga & Lab. Baristan samarinda & SNI 6989.6-2009 \\
Timbal (Pb) & Lab. Baristan samarinda & SNI 6989.8-2009 \\
Seng (Zn) & Lab. Baristan samarinda & SNI 6989.7-2009 \\
Nikel (Ni) & Lab. Baristan samarinda & SNI 6989.18-2009 \\
Minyak dan Lemak & Lab. Baristan samarinda & SNI 06-6989.10-2004 \\
Detergen (MBAS) & Lab. Baristan samarinda & SNI 06-6989.51-2005 \\
Fenol & Lab. Baristan samarinda & SNI 06-6989.21-2004 \\
Parameter Biologi & Lab. Baristan samarinda & \\
E. Coli & Lab. Baristan samarinda & Colilert \\
Total Coliform & Colilert \\
\hline Sumber Baristand Samata &
\end{tabular}

Sumber : Baristand Samarinda (2020)

Tabel 3 Data Kualitas Air di 6 (enam) lokasi pengamatan perairan laut Kota Bontang

\begin{tabular}{|c|c|c|c|c|c|c|c|c|}
\hline Parameter & Satuan & $\begin{array}{l}\text { Baku } \\
\text { mutu }\end{array}$ & LT 1 & LT 2 & BK 1 & BK 2 & TL 1 & TL 2 \\
\hline \multicolumn{9}{|l|}{ Parameter Fisika } \\
\hline Suhu & ${ }^{\circ} \mathrm{C}$ & $28-32$ & 33,5 & 32,75 & 30,5 & 30 & 30,5 & 30,5 \\
\hline $\mathrm{pH}$ & & $7-8,5$ & 6,5 & 7 & 7,25 & 7,5 & 7,5 & 7,5 \\
\hline TSS & $\mathrm{mg} / \mathrm{L}$ & 80 & 175 & 181 & 168 & 168 & 156 & 173 \\
\hline \multicolumn{9}{|l|}{ Parameter Kimia } \\
\hline BOD & $\mathrm{mg} / \mathrm{L}$ & 20 & 1,85 & 1,92 & 1,91 & 1,97 & 1,93 & 1,82 \\
\hline Amonia (NH3) & $\mathrm{mg} / \mathrm{L}$ & 0,3 & 1,1 & 1,03 & 0,051 & 0,024 & 0,029 & 0,013 \\
\hline Fosfat & $\mathrm{mg} / \mathrm{L}$ & 0,015 & $<0,0009$ & $<0,0009$ & $<0,0009$ & $<0,0009$ & $<0,0009$ & $<0,0009$ \\
\hline Nitrat (NO3-N) & $\mathrm{mg} / \mathrm{L}$ & 0,008 & 0,46 & 0,442 & 0,387 & 0,455 & 0,097 & 0,041 \\
\hline Raksa (Hg) & $\mathrm{mg} / \mathrm{L}$ & 0,003 & $<0,0001$ & $<0,0001$ & $<0,0001$ & $<0,0001$ & $<0,0001$ & $<0,0001$ \\
\hline Arsen (As) & $\mathrm{mg} / \mathrm{L}$ & 0,012 & 0,012 & $<0,0003$ & $<0,0003$ & $<0,0003$ & $<0,0003$ & $<0,0003$ \\
\hline Kadmium (Cd) & $\mathrm{mg} / \mathrm{L}$ & 0,01 & 0,01 & $<0,0001$ & $<0,0001$ & $<0,0001$ & $<0,0001$ & $<0,0001$ \\
\hline Tembaga (Cu) & $\mathrm{mg} / \mathrm{L}$ & 0,05 & 0,05 & $<0,013$ & $<0,013$ & $<0,013$ & $<0,013$ & $<0,013$ \\
\hline Timbal (Pb) & $\mathrm{mg} / \mathrm{L}$ & 0,05 & 0,138 & 0,188 & 0,150 & 0,138 & 0,238 & 0,225 \\
\hline Seng $(Z n)$ & $\mathrm{mg} / \mathrm{L}$ & 0,1 & 0,010 & $<0,006$ & $<0,006$ & $<0,006$ & $<0,006$ & $<0,006$ \\
\hline Nikel (Ni) & $\mathrm{mg} / \mathrm{L}$ & 0,05 & $<0,04$ & $<0,04$ & $<0,04$ & $<0,04$ & $<0,04$ & $<0,04$ \\
\hline Minyak dan & $\mathrm{mg} / \mathrm{L}$ & 5 & 0,180 & 0,203 & 0,414 & 0,068 & 0,141 & 0,046 \\
\hline Lemak & & & & & & & & \\
\hline $\begin{array}{l}\text { Detergen } \\
\text { (MBAS) }\end{array}$ & $\mathrm{mg} / \mathrm{L}$ & 1 & 0,435 & 0,410 & 0,475 & 0,425 & 0,439 & 0,449 \\
\hline $\begin{array}{l}\text { Fenol } \\
\text { Paramater Biologi }\end{array}$ & $\mathrm{mg} / \mathrm{L}$ & 0,002 & 0,001 & 0,001 & 0,002 & 0,002 & 0,008 & 0,008 \\
\hline E. Coli & $\mathrm{MPN} / 100 \mathrm{ml}$ & 200 & 75 & 41 & 41 & $<1$ & $<1$ & $<1$ \\
\hline Total Coliform & MPN/100ml & 1000 & 2481 & 2247 & 1793 & 993 & 1793 & $<1$ \\
\hline
\end{tabular}

Sumber : Data diolah dari Baristand Samarinda (2020) 


\section{HASIL DAN PEMBAHASAN}

Dari hasil pengukuran parameter fisika, kimia dan biologi perairan dapat diketahui Tingkat kualitas perairan Kota Bontang yang selanjutnya akan dianalisis secara deskriptif dengan membandingkan dengan standar baku mutu lingkungan air untuk biota dan wisata bahari berdasarkan Keputusan Menteri Lingkungan Hidup Nomor 51 Tahun 2004. Adapun data kualitas air dari 6 (enam) stasiun disajikan pada tabel 3. Dari hasil yang diperoleh (tabel 3) menunjukan bahwa terdapat beberapa parameter yang tidak sesuai dengan baku mutu pada ke6 (enam) stasiun yaitu parameter suhu, pH, Total Suspended Solid (TSS), Amonia, Nitrat, Timbal dan Total Coliform.

\section{Suhu Perairan}

Salah satu faktor yang sangat penting bagi kehidupan organisme di perairan yaitu suhu perairan dimana walaupun suhu merupakan faktor eksternal yang paling mudah untuk diteliti dan ditentukan namun sangat berpengaruh terhadap aktivitas metabolisme dan penyebaran organisme air (Nontji, 2005). Beberapa hal yang mempengaruhi suhu pada badan air diantaranya musim, lintang, waktu dalam hari, sirkulasi udara, penutupan awan dan aliran serta kedalaman air. Suhu perairan sangat berperan dalam mengendalikan kondisi ekosistem perairan karena terjadinya perubahan suhu permukaan akan mempengaruhi proses fisik, kimia dan biologi di perairan tersebut (Kusumaningtyas et al., 2014). Sebagaimana hasil penelitian dari Effendi (2003) bahwa peningkatan suhu akan menyebabkan terjadinya stratifikasi atau pelapisan air yang akan berpengaruh terhadap pengadukan air yang sangat diperlukan dalam penyebagaean oksigen sehingga dengan adanya pelapisan air tersebut di lapisan dasar menjadi tidak anaerob.

Hasil pengukuran suhu permukaan laut langsung secara langsung di lapangan (insitu), diperoleh bahwa suhu di perairan Kota Bontang berkisar antara 30,5 $-33,5^{\circ} \mathrm{C}$ (gambar 2). Berdasarkan Keputusan Menteri Negara Lingkungan Hidup No. 51 tahun 2004 bahwa ambang baku mutu untuk suhu adalah $28-32^{\circ} \mathrm{C}$ dimana suhu yang melebihi baku mutu adalah stasiun LT 1 dan LT 2 yaitu $33,5^{\circ} \mathrm{C}$ dan $32,75^{\circ} \mathrm{C}$.

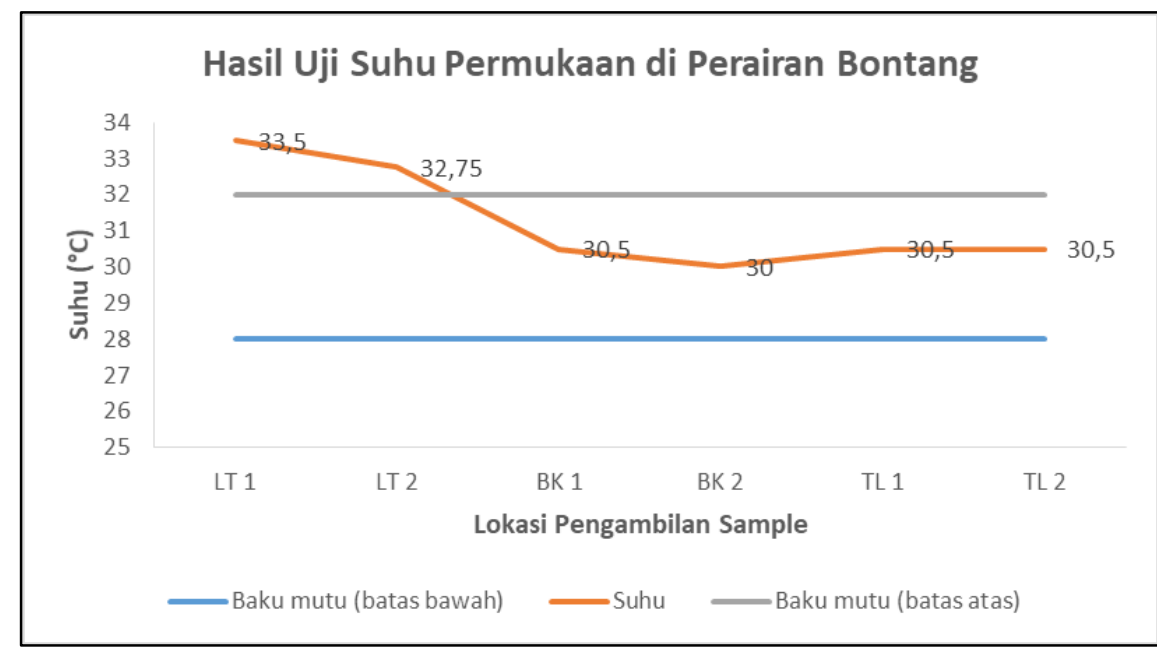

Gambar 2 Hasil Uji Suhu Permukaan di Perairan Bontang Sumber : Hasil Analisis (2020)

\section{pH (Derajat Keasaman)}

Yang dimaksud dengan Derajat Keasaman $(\mathrm{pH})$ merupakan logaritma negatif dari konsentrasi ion-ion hidrogen yang terlepas dalam suatu cairan dan merupakan indikator baik buruknya suatu perairan. Menurut Simanjuntak (2009) bahwa pH perairan merupakan salah 
satu parameter kimia penting dalam memantau kestabilan perairan. Biota di perairan sangat dipengaruhi oleh variasi $\mathrm{pH}$ dimana tingginya nilai $\mathrm{pH}$ akan sangat menentukan dominasi fitoplankton yang akan berdampak para tingkat produktivitas primer suatu perairan karena keberadaan fitoplankton sangat didukung oleh ketersediaan nutrient di perairan laut (Megawati etal, 2014). Selain itu, kondisi perairan yang terlalu basa maupun terlalu asam akan membahayakan bagi kehidupan organisme karena akan mengganggu proses metabolisme dan respirasi.

Dari hasil pengukuran, $\mathrm{pH}$ di Perairan Kota Bontang berkisar antara 6,5 - 7,5 dimana bila dibandingkan dengan Keputusan Menteri Negara Lingkungan Hidup No. 51 Tahun 2004 bahwa ambang baku mutu $\mathrm{pH}$ yaitu 7 - 8,5 maka $\mathrm{pH}$ di perairan laut Kota Bontang berada pada ambang baku mutu yang dianjurkan untuk biota laut kecuali pada stasiun LT 1 yaitu 6,5 (gambar 3). Rendahnya $\mathrm{pH}$ hasil pengukuran dapat saja terjadi karena $\mathrm{pH}$ di suatu perairan dipengaruhi oleh beberapa faktor antara lain aktivitas fotosintesa biota laut, suhu dan salinitas perairan. Kisaran $\mathrm{pH}$ hasil pengukuran yang diperoleh tersebut masih dapat ditolerir karena menurut Odum (1971) bahwa nilai $\mathrm{pH}$ antara 6,5 -8,0 sebagai batas aman $\mathrm{pH}$ perairan untuk kehidupan biota di dalamnya.

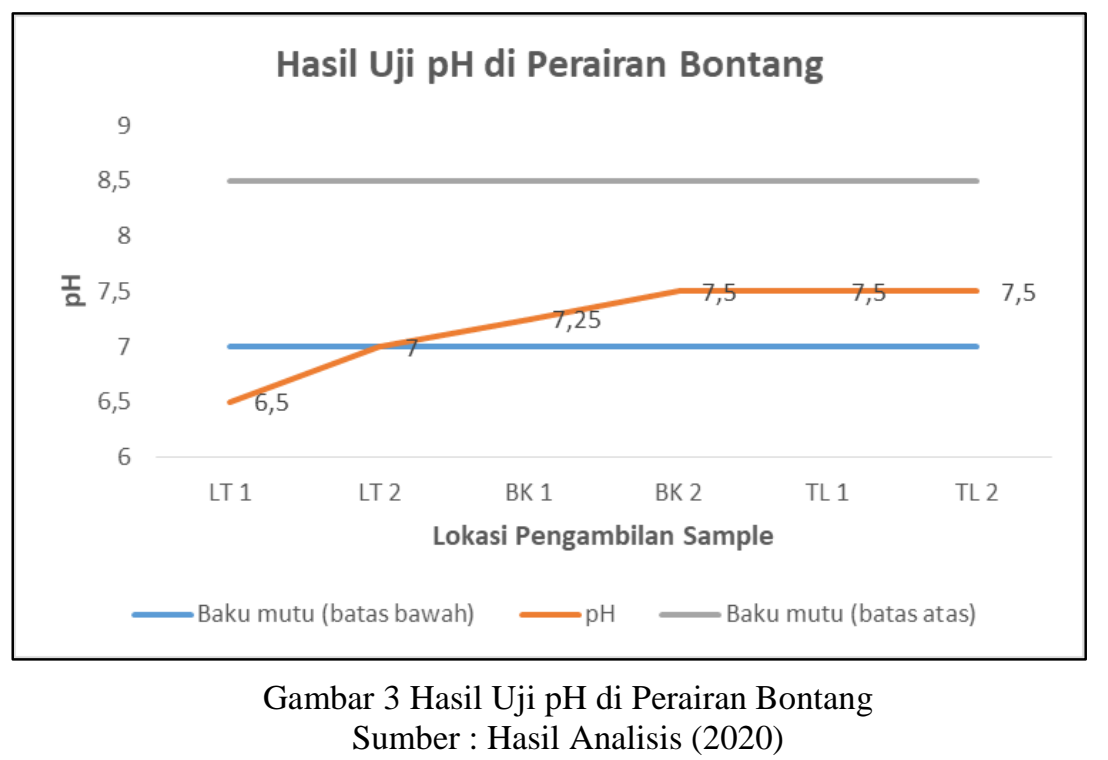

\section{Total Suspension Solid (TSS) atau Padatan Tersuspensi Total}

Menurut Effendi (2003) bahwa TSS terdiri atas lumpur dan pasir halus serta jasad-jasad renik, yang umumnya disebabkan oleh kikisan tanah atau erosi yang terbawa ke badan air. TSS sangat mempengaruhi penetrasi cahaya matahari ke kolam air karena dapat meningkatkan nilai kekeruhan yanga pada akhirnya akan mempengaruhi proses fotosintesis oleh fitoplankton dan tumbuhan air sehingga berdampak pada pasokan oksigen terlarut yang berkurang dan meningkatkan pasokan $\mathrm{CO}_{2}$ di perairan.

Hasil pengukuran diketahui nilai TSS di perairan Kota Bontang berkisar antara 156-175 $\mathrm{mg} / \mathrm{l}$ dimana bila dibandingkan dengan standar baku mutu air laut untuk biota oleh Kementerian Lingkungan Hidup No.51 Tahun 2004 berada di atas baku mutu yaitu $80 \mathrm{mg} / \mathrm{l}$ (gambar 4). Nilai TSS yang tinggi melebihi ambang baku mutu secara tidak langsung akan mempengaruhi kehidupan organisme karena akan meningkatkan kekeruhan perairan sehingga berpengaruh terhadap proses fotosintesis. Hal ini akan berdampak pada terganggunya kehidupan dan perkembangan biota serta dapat menyebabkan kematian biota dikarenakan dapat menutup insang dan saluran pernafasan (effendi 2003). Dari hasil penelitan Wardoyo (1891) 
juga menyebutkan bahwa TSS yang tinggi dapat mengurangi proses fotosintesis yang pada akhirnya akan memusnahkan sumberdaya perikanan di daerah pemijahan (spawning area).

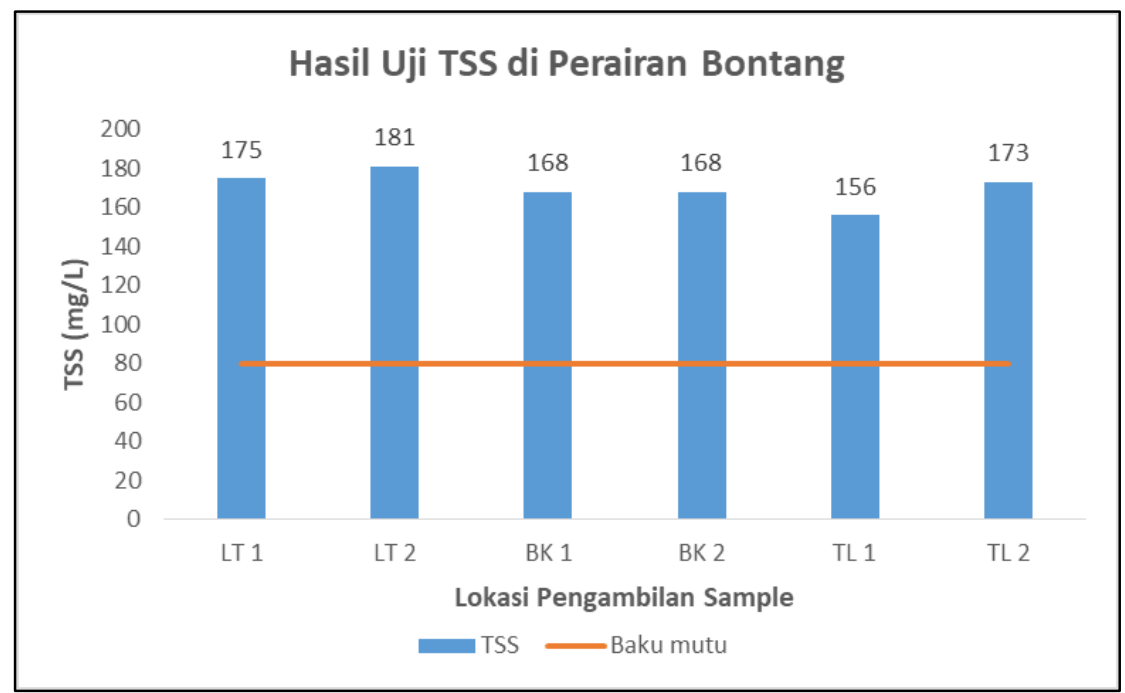

Gambar 4 Hasil Uji TSS di Perairan Bontang

Sumber : Data diolah dari Baristand Samarinda (2020)

\section{Amonia $\left(\mathbf{N H}_{3}\right)$}

Amonia termasuk dalam salah satu parameter yang terdapat dalam Peraturan Menteri Lingkungan Hidup Republik Indonesia Nomor 5 Tahun 2014 Tentang Baku Mutu Air Limbah. Berdasarkan hasil uji laboratorium diperoleh bahwa kadar Amonia (NH3) di stasiun pengambilan sample berkisar antara 0,013 - 1,1 mg/l dimana nilai Amonia yang tinggi dan melebihi ambang baku mutu berdasarkan Keputusan Menteri Lingkungan Hidup Nomor 5 Tahun 2004 yaitu 0,3 mg/l berada di stasiun LT 1 dan LT 2 (gambar 5). Konsentrasi amonia yang tinggi pada permukaan air akan menyebabkan kematian ikan yang terdapat pada perairan tersebut. Toksisitas amonia dipengaruhi oeh $\mathrm{pH}$ yang ditunjukkan dengan kondisi $\mathrm{pH}$ rendah akan bersifat racun jika jumah amonia banyak, sedangkan dengan kondisi $\mathrm{pH}$ tinggi hanya dengan jumlah amonia yang sedikit akan bersifat racun. Kadar amonia yang tinggi dapat merupakan indikasi adanya pencemaran bahan organik yang berasal dari limbah domestik, industri, dan limpasan pupuk pertanian.

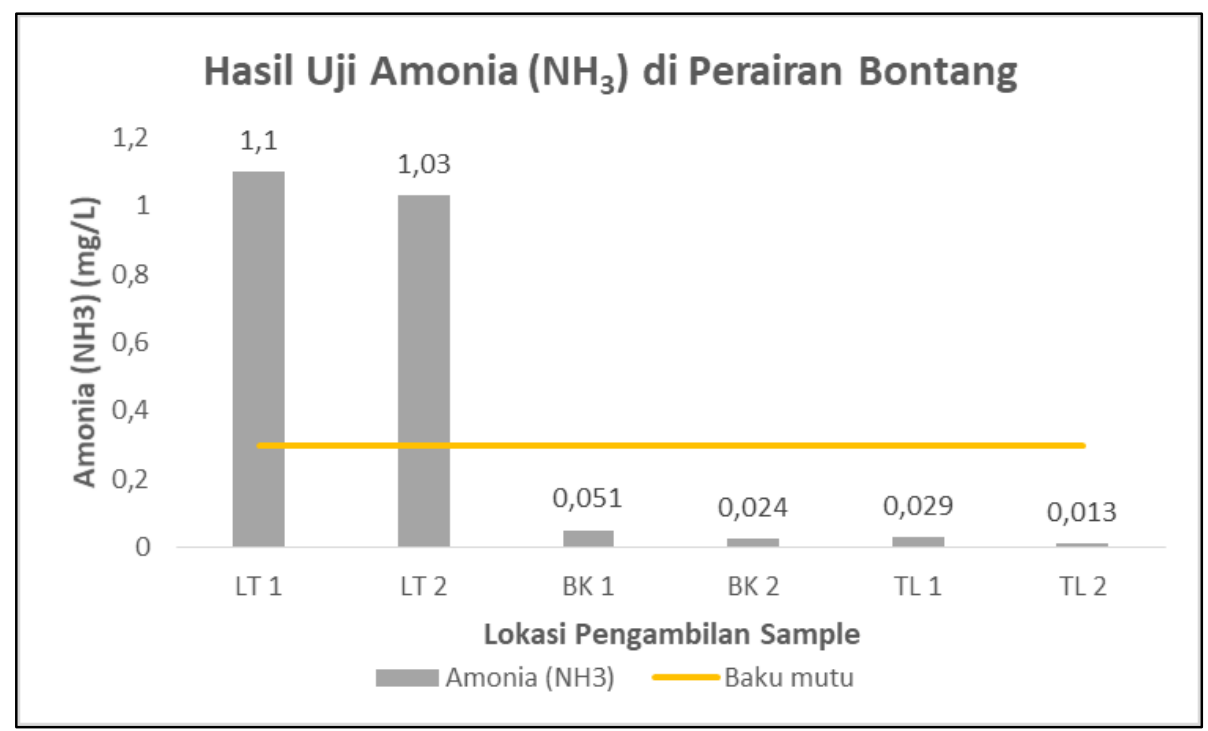

Gambar 5 Hasil Uji Amonia $\left(\mathrm{NH}_{3}\right)$ di Perairan Bontang

Sumber : Data diolah dari Baristand Samarinda (2020) 


\section{Nitrat $\left(\mathrm{NO}_{3}-\mathrm{N}\right)$}

Menurut Efendi (2003), Konsentrasi nitrat yang tinggi di perairan dapat dapat menstimulasi pertumbuhan dan perkembangan organisme perairan apabila didukung oleh ketersediaan nutrient. sehingga bila nilai nitrat yang terkonsentrasi di perairan melebihi 0,2 $\mathrm{mg} / \mathrm{l}$ dapat mengakibatkan terjadinya eutrofikasi (pengayaan) perairan dan selanjutnya menstimulir pertumbuhan alga dan tumbuhan air secara pesat

Hasil pengukuran menunjukkan nilai nitrat pada stasiun pengamatan berkisar antara 0,041 -0,46 mg/l. Untuk stasiun LT 1, LT 2, BK 1 dan BK 2 melebihi standar baku mutu, dimana standar baku mutu air laut berdasarkan Keputusan Menteri Lingkungan Hidup Nomor 5 Tahun 2004 Tentang Baku Mutu Air Limbah untuk biota adalah 0,008 mg/l (gambar 6). Tingginya nilai nitrat di titik sampling ini kemungkinan bersumber dari masukan bahan organik akibat aktivitas dari daratan yang dapt berupa erosi daratan, masukan limbah rumah tangga, limbah pertanian berupa sisa pemupukan dan lainnya.

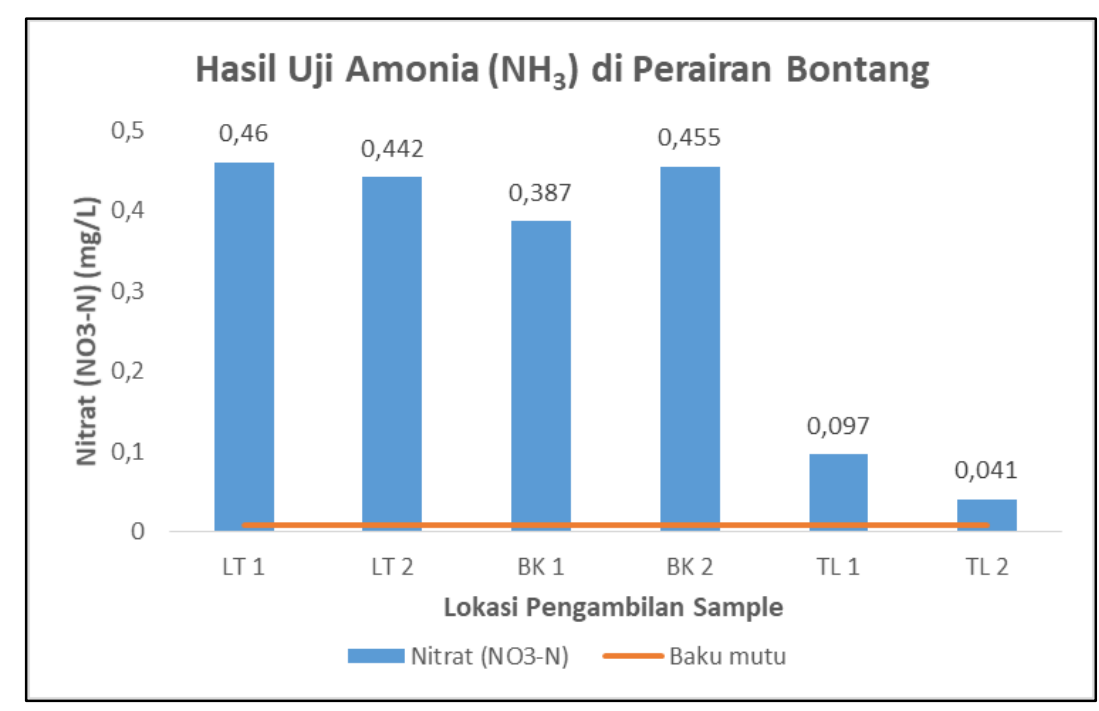

Gambar 6 Hasil Uji Nitrat $\left(\mathrm{NO}_{3}-\mathrm{N}\right)$ di Perairan Bontang Sumber : Data diolah dari Baristand Samarinda (2020)

\section{Timbal (Pb)}

Timbal $(\mathrm{Pb})$ merupakan salah satu logam berat yang masuk dalam kelompok bersifat toksisitas tinggi selain $\mathrm{HG}, \mathrm{Cd}, \mathrm{Cu}$ dan $\mathrm{Zn}$ menurut Kementrian Negara Kependudukan dan Lingkungan Hidup (1990). Karena sifat toksisitasnya yang tinggi, logam berat timbal $(\mathrm{Pb})$ tidak diharapkan keberadaannya dalam tubuh makhluk hidup meskipun dalam jumlah yang sangat kecil. Namun disisi lain, Timbal $(\mathrm{Pb})$ sangat banyak membantu dalam kehidupan manusia sehari-hari, dimana menurut Lu (1994) bahwa Pb sangat dibutuhkan dalam industry sebagai bahan bakar, kendaraan bermotor, pabrik kertas, pabrik kayu, pelelehan baju, pembuatan cat maupun aki mobil.

Dari hasil laboratorium diperoleh bahwa kandungan timbal di perairan laut Kota Bontang pada saat pengambilan sample melebihi ambang baku mutu yang telah ditetapkan oleh Keputusan Menteri Lingkungan Hidup No. 51 Tahun 2004 yaitu 0,05 mg/l sedangkan hasil pengukuran berkisar antara $0,138-0,238 \mathrm{mg} / \mathrm{l}$ (gambar 7). Tingginya kadar $\mathrm{Pb}$ diperairan tersebut kemungkinan diakibatkan oleh aktivitas industry, cat, pengawet kayu, minyak pelumas, komponen mesin dan BBM dalam aktifitas pelayaran serta berasal dari kegiatan domestik. Selain itu Kandungan logam dalam air dapat berubah-ubah atau sangat tergantung pada lingkungan dan iklim. Pada musim hujan kandungannya lebih kecil karena proses 
pelarutan, sedangkan pada musim kemarau kandungannya lebih tinggi karena logam dalam air lebih terkonsentrasi.

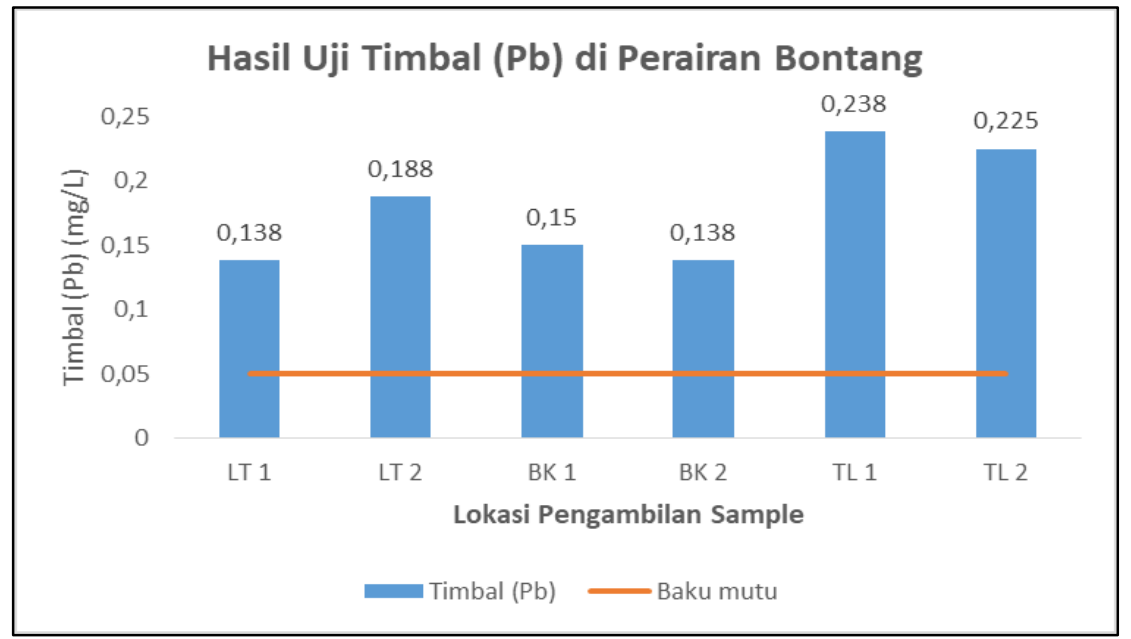

Gambar 7 Hasil Uji Timbal $(\mathrm{Pb})$ di Perairan Bontang

Sumber : Data diolah dari Baristand Samarinda (2020)

\section{Total Coliform}

Menurut Treyens (2009) bahwa bakteri coliform merupakan golongan bakteri yang hidup di dalam saluran pencernaan. Adanya bakteri coliform dalam air mengindikasi bahwa air tersebut terkontaminasi oleh tinja yang bersifat pathogen dalam usus sehingga tidak layak untuk dikonsumsi (Sopacua. Dkk, 2013). Semakin banyak jumlah coliform artinya semakin buruk kualitas air tersebut.

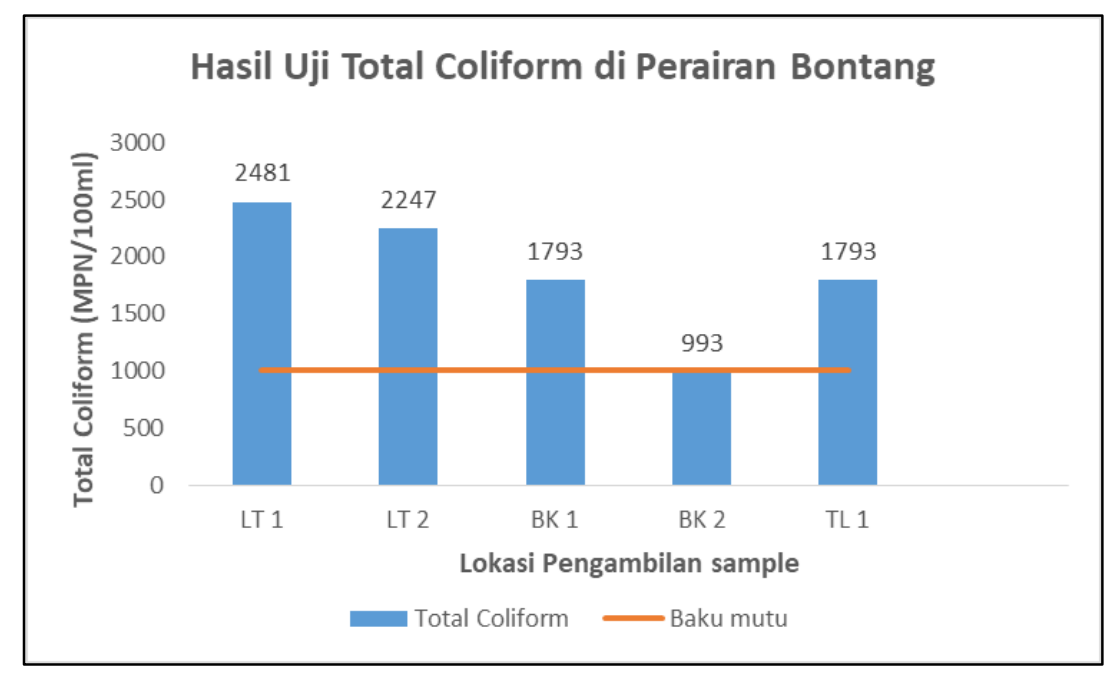

Gambar 8 Hasil Uji Total Coliform di Perairan Bontang Sumber : Data diolah dari Baristand Samarinda (2020)

Berdasarkan gambar 8, dari hasil pengukuran uji kualitas perairan di 6 (enam) stasiun berada di bawah baku mutu Keputusan Menteri Lingkungan Hidup No. 51 Tahun 2004. Hal ini dapat disebabkan oleh kotoran manusia dan limbah domestik dari pemukiman di lokasi wisata di Bontang Kuala maupun sepanjang aliran Sungai Bontang yang kurang terkelola karena seiring dengan perkembangan jumlah penduduk, berkurangnya ketersediaan air bersih mengakibatkan kemampuan tanah untuk menyerap air dengan sempurna menjadi semakin kurang akibatnya bakteri coliform dapat mengkontaminasi sumber dan badan air (Bambang dkk., 2014). Total coliform yang tinggi melebihi ambang baku mutu yang telah ditetapkan akan 
berbahaya bagi kesehatan masyarakat sekitar terutama bagi masyakat yang bermukim di perumahan yang tidak terencana (Sumantri, 2011).

\section{KESIMPULAN}

Kualitas lingkungan perairan Kota Bontang berdasarkan hasil dari pengukuran baik insitu maupun hasil analisis laboratorium baik untuk parameter fisika, kimia dan biologi diperoleh bahwa beberapa parameter di beberapa stasiun berada tidak sesuai dengan baku mutu menurut Keputusan Menteri Lingkungan Hidup Nomor 51 Tahun 2004 yaitu parameter suhu, pH, Total Suspended Solid (TSS), Amonia, Nitrat, Timbal dan Total Coliform. Parameter yang melebihi baku mutu akan berdampak pada terganggunya fungsi ekologi ekosistem di perairan dan terjadinya penurunan kualitas air laut baik secara fisik, kimia maupun biologi yang berakibat pada penurunan daya guna, hasil guna, produktivitas, daya dukung dan daya tampung sumberdaya perairan sehingga pada akhirnya akan menurunkan kekayaan sumberdaya alam.

\section{REKOMENDASI}

Adapun rekomendasi pada penelitian kali ini adalah sebagai berikut:

1. Perlu adanya kajian lebih mendalam mengenai Indeks Kualitas Pencemaran Laut di Perairan Kota Bontang.

2. Harus terus dilakukan pemantauan kualitas perairan di Kota Bontang agar kondisi perairan tetap terpantau dan terjaga.

3. Semua usaha wajib melakukan pengelolaan limbah sebelum dibuang ke lingkungan.

\section{UCAPAN TERIMA KASIH}

Terima kasih kami ucapkan kepada Balitbangda Provinsi Kalimantan Timur yang telah memberikan dana penelitian serta kepada Pemerintah Kota Bontang yang telah membantu dalam pengumpulan data dan informasi dalam penelitian ini.

\section{DAFTAR PUSTAKA}

Bambang, A.G., Fatimawali., Kojong, S.N. 2014. Analisis Cemaran Bakteri Coliform dan Identifikasi Escherichia Coli Pada Air Isi Ulang Dari Depot di Kota Manado.Jurnal Ilmiah Farmasi UNSRAT. 3 (3): 325 - 334.

Cordova, Muhammad Reza. 2011. Identifikasi Industri Berdasarkan Limbah yang Menunjang Perekonomian Nelayan Namun Relatif Menurunkan Kualitas Air Dan Produksi Perikanan. Jurnal Pengelolaan Sumber Daya Alam dan Lingkungan. 1 (2): 120 - 126. doi: 10.29244/jpsl.1.2.120.

Darmono. 1995. Logam Dalam Sistem Biologi Makhluk Hidup. Jakarta (ID): Penerbit UI- Press.

Effendi, Hefni. 2003. Telaah kualitas air bagi pengelolaan sumber daya dan lingkungan perairan. Yogyakarta (ID): Kanisius.

Hamuna, Baigo dkk. 2018. "Kajian Kualitas Air Laut dan Indeks Pencemaran Berdasarkan Parameter Fisika-Kimia Di Perairan Distrik Depapre, Jayapura". Jurnal Ilmu Lingkungan. 16 (1): $35-43$.

Kusmaningtyas, dkk. 2014. "Kualitas perairan Natuna pada musim transisi”. Depik Unsyiah. 3 (1): $10-20$.

Lu, B. McBride, B.C. 1994. "Stress response of Porphyromonas gingivalis". Oral Microbiology and Immunology. 9 (3): 166 - 173. 
Megawati, Christina. dkk. 2014. "Sebaran Kualitas Perairan Ditinjau dari Zat Hara, Oksigen Terlarut dan pH Di Perairan Selat Bali Bagian Selatan”. Jurnal Oseanografi.3 (2): 142 -150 .

Odum, Eugene P. 1971. Fundamentals of ecology. London (UK): W.B. Saunders.

Simanjuntak, Marojahan. 2009. "Hubungan Faktor Lingkungan Kimia, Fisika Terhadap Distribusi Plankton Di Perairan Belitung Timur, Bangka Belitung”. Jurnal Perikanan UGM. 11 (1): $31-45$.

Sopacua, F.C., Purwijatiningsih, L.M.E., Pranata, S., 2013. Kandungan Coliform dan klorin es batu di Yogyakarta. Jurnal Ilmiah Biologi. 9: 1-9.

Sumantri, Arif. Muhammad Reza Cordova. 2011. Dampak Limbah Domestik Perumahan Skala Kecil Terhadap Kualitas Air Ekosistem Penerimanya Dan Dampaknya Terhadap Kesehatan Masyarakat. Jurnal Pengelolaan Sumber Daya Alam dan Lingkungan. 1 (2): 127 - 134. doi: 10.29244/jpsl.1.2.127.

Taguge, Ayisman. Abd Fafidz Olii. Dan Citra.P. 2014. "Studi Status Kandungan Logam Berat Timbal di Perairan Sekitar Pelabuhan Kota Gorontalo". Jurnal Ilmiah Perikanan dan Kelautan UNG. 2 (1): 14 - 17).

Treyens, C. (2009). "Bacteria and Private Wells: Information Every Well Owner Should Know." National Ground Water Association. 8 (4): 19-21.

Wahjuningsih, Endang. 2001. "Substrat Khromogenik-Fluorogenik pada Uji Cemaran Koli dalam Air". Jurnal Unitas Ubaya. 9 (2): 44 - 56.

Wardoyo, S.T.H. 1981. "Kriteria Kualitas Air untuk Keperluan Pertanian dan Perikanan". Makalah Training AMDAL. Kerjasama PPLH-UNDEP-PUSDL $\neg$ PSL. 19-31, Januari, 1981. Bogor (ID). 